WOJCIECH ADAMOWSKI ${ }^{1} \&$ ANNA BOMANOWSKA ${ }^{2}$

\author{
${ }^{1}$ Białowieża Geobotanical Station, Warsaw University, Sportowa 19, 17-230 \\ Białowieża, Poland,w.adamowski@uw.edu.pl \\ ${ }^{2}$ Department of Geobotany and Plant Ecology, University of Lodz, Banacha 12/16, \\ 90-237 Łódź, Poland, knopikaa@biol.uni.lodz.pl
}

\title{
FOREST RETURN ON AN ABANDONED FIELD - SECONDARY SUCCESSION UNDER MONITORED CONDITIONS
}

\begin{abstract}
The secondary succession pattern observed on an arable field abandoned since 1974 in Tilio-Carpinetum habitat is described and disscussed. Results obtained during 36 years of study confirm that succession on an abandoned field leads from a typical segetal community to the formation of a juvenile treestand composed of pioneer species. Our study supports the view that succession is a process which is largely dependent on the initial conditions and surrounding vegetation. The results indicate that some species can modify the course of this process, accelerating or slowing it down. Limitations of the method and prognosis of future vegetation development are also discussed.
\end{abstract}

Key words: abandoned field, long-term study, permanent plots, species turnover, vegetation succession, Białowieża Forest, Poland

\section{INTRODUCTION}

Secondary succession, i.e. the restoration of forest communities after their destruction by natural factors or anthropogenic activity, is one of the most frequently analysed problems in studies on vegetation dynamics. Two principal methods are used to study this process. The first, and most popular, is that of chronosequence based on a description of floristic compositions developed at a certain time or at a 
predicted time (e.g. Conell, Slatyer 1977; Vankat, SNyder 1991; Brady, NOSKE 2010); the second, less popular method is based on the long-term observation of permanent plots (FALIŃSKI 2003; BORNKAMM 2007). Both research approaches have their theoretical and practical limitations (see CONELL, SLATYER 1977; FOSTER, Tilman 2000; FALIŃSKa 2003; JOHNSON, MYIANiShi 2008), which is why some authors strongly recommend their complementary use (BAKKER et al. 1996; FOSTER, TILMAN 2000; BORNKAMM 2007; Myster, MALAHY 2008). The integration of the two methods is difficult owing to the shortage of data obtained from a many-years' observation series, as such a study requires follow-up of the process for twenty plus years or even centuries, which is longer than a researcher's life (CONELL, SLATYER 1977; FALIŃSKI 2001, 2003).

Regardless of these difficulties, such studies are conducted because permanent plot studies with precise documentation of vegetation changes over long periods of time are thus of great interest in the testing of ecological models and hypotheses (BAKKER et al. 1996; FALIŃSKI 2003; BLATT et al. 2005; SCHMIDT 2006).

An example of these long-term studies on secondary succession are studies conducted since 1974 on permanent plots at the Experimental Ecological Garden of the Białowieża Geobotanical Station, Warsaw University, initiated and coordinated for many years by Professor Janusz Bogdan Faliński (FALIŃsKI 1986, 2002). According to the authors' knowledge, this is the longest series of direct observations of old-field succession in Poland, and one of very few as long in Europe (PICKETT 1982; Osbornová et al. 1990; DeBUSSCHE et al. 1996; BALCERKIEWICZ, PAWLAK 2006; DöLLE et al. 2008).

Results of the studies conducted in Białowieża have been partly published (FALIŃSKI 1986; ADAMOWSKI, KNOPIK 1996; FALIŃSKI et al. 2004; ADAMOWSKI, BOMANOWSKA 2007a, 2007b, 2007c; BOMANOWSKA, ADAMOWSKI 2007a, 2007b, 2009). The main objectives of the current study are: i) to identify a successional pathway characterised by a sequence of different stages; ii) to indicate factors influencing change in the pathway of the studied process which do not occur, or 
whose intensity is different, during the succession undisturbed by anthropogenic activity.

\section{MATERIAL AND METHODS}

The Experimental Ecological Garden of the Białowieża Geobotanical Station (BGS) of Warsaw University is located in the central part of the Białowieża Clearing, in typical subcontinental oak-hornbeam forest Tilio-Carpinetum typicum habitat. This area had been in agricultural use since the late $17^{\text {th }}$ century, up to the moment of its acquisition by the BGS (FALIŃSKI 1986). The Garden came into existence in 1974 on an area of 1.2 ha in the location of a former arable field and mown meadow. The last cultivation, in 1973, were potatoes and cabbage, which were accompanied by a segetal community, Echinochloo-Setarietum, while the meadow was described as belonging to the Arrhenatheretum elatioris association (FALIŃSKI 1986, 2002). The garden is surrounded by a fence and divided into sectors connected by roads with a hardened surface.

Two sectors were selected for long-term observations on the initiation and progress of secondary succession on an abandoned field and meadow under monitored conditions: sectors $\mathrm{C}$ and $\mathrm{E}$, each with an area of $400 \mathrm{~m}^{2}$. Both permanent study areas are divided into 22 basic plots, each with an area of $10 \mathrm{~m}^{2}(6.25 \mathrm{~m} \mathrm{x} 1.6$ $\mathrm{m})$, separated by paths with a width of $30 \mathrm{~cm}$. The plots are surrounded by an isolating belt which is $120-220 \mathrm{~cm}$ wide. A detailed description of the site of the experiment, its habitat conditions and the treatments used can be found in earlier papers by FALIŃSKI (1977, 1986, 2002), ADAMOWSKI and KNOPIK (1996) as well as BOMANOWSKA and ADAMOWSKI (2007a).

Regular observations have been conducted (since 1974) once a year, around the end of June and the beginning of July. Until 1995 all the observations were carried out by Prof. Aurelia U. WARCHOLIŃSKA, and are continued at present by the authors of this paper. The following features were recorded: overall species composition, structure of the plant community, appearance of seedlings and juvenile individuals of woody species (all seedlings were marked and mapped during the first 21 years). To fulfil this goal, a phytosociological relevé was recorded from each 
basic plot by the classical Braun-Blanquet method, while cover for each species was assessed in the numerical scale of Braun-Blanquet and in the decimal scale of Londo (DZWONKO 2007). Since 2000 the occurrence of spring geophytes has been recorded at the end of April or the beginning of May. Since 1984, additional observations have been conducted in sector $\mathrm{F}$, which is used to evaluate the effects of the anthropogenic modification of the secondary succession process by controlled mowing (FALIŃSKI 2002; ADAMOWSKI, BOMANOWSKA 2009).

The data used in this work were collated in the BGS archive and obtained from sector C (former arable field). Data from 17 observation plots were included in the analysis $\left(=170 \mathrm{~m}^{2}\right)$ because in the five remaining ones $(\mathrm{C} 1-\mathrm{C} 3, \mathrm{C} 12$ and $\mathrm{C} 13)$ since 1984 plants have been mown each year after observation and the biomass was removed from the plot.

The total cover of plants was calculated from the cover index values for individual species, estimated using Londo scale. The following conversion factors for Londo scale were adopted: $0.1-0.5 \%$ cover, $0.2-2 \%, 0.4-5 \%, 1-10 \%, 2-$ $20 \%, 3-30 \%$, etc.

The succession pattern was established based on observation data (see above), as well as literature data regarding the maximum age of individual tree species and their role in forest communities (ZARZYCKI 1979; FALIŃSKI 1997, 1998; FALIŃSKI, PAWLACZYK 1991, 1993; DANIELEWICZ, PAWLACZYK 2006).

The Latin names of vascular flora were used according to MIREK et al. (2002).

\section{RESULTS}

1. During 36 years of observation in the experimental area, 224 vascular plant species classified to 46 families were recorded in total (Fig. 1). Families represented by the highest number of species included: Asteraceae (34 species), Poaceae (27) and Rosaceae (23).

2. During individual years of the experiment, the number of recorded species ranged from 80 to 107 (Fig. 2). The lowest number of species was recorded in year 13 of the study, and the highest number in year 31 of the study. 
3. Initially, species composition was dominated by short-lived plants associated with arable lands, which were quickly replaced by perennials and later by woody species. The number of perennials reached its maximum in year 7 of observation (Fig. 2).

4. During the first years of the experiment an important role among short-lived plants was played by segetal species remaining after the primary community. During the first year of observation 36 segetal species were recorded, but their number rapidly decreased, and only 6 species were recorded in year 6 of observation. The cover of this species group decreased rapidly along with the progress of secondary succession from approximately $35 \%$ in the first year to $1 \%$ in year 6 (Fig. 3).

5. Three Vicia species were an exceptional case in this group (Vicia angustifolia, $V$. hirsuta and V. tetrasperma), and they reached a maximum cover rate as late as in years 7 and 10 of observation (Fig. 3). Up to the present time they demonstrate significant frequency, and flower and produce fruits.

6. Between the second and fourth observation year the study site was dominated by Elymus repens, which attained over $40 \%$ of cover (Fig. 4).

7. After the withdrawal of short-lived species during the following dozen or more years (especially between years 5 and 16 of the experiment) a significant role was played by perennials, including grasses. The two most frequent meadow species (Leontodon hispidus and Dactylis glomerata) had the highest cover rate in years 15 and 16 of observation respectively, which was followed by their withdrawal (Fig. 5).

8. Despite the withdrawal of the vast majority of perennial meadow species, the cover of two grass species (Arrhenatherum elatius and Poa palustris; Fig. 6) still continues to increase.

9. In total, 55 tree and shrub species have occurred on experimental plots during the 36 years of observation. The first seedlings (Betula, Populus, Salix, Acer, Fraxinus) emerged early, in year 2 of observation, but for many years their share in the herb layer cover was insignificant. 


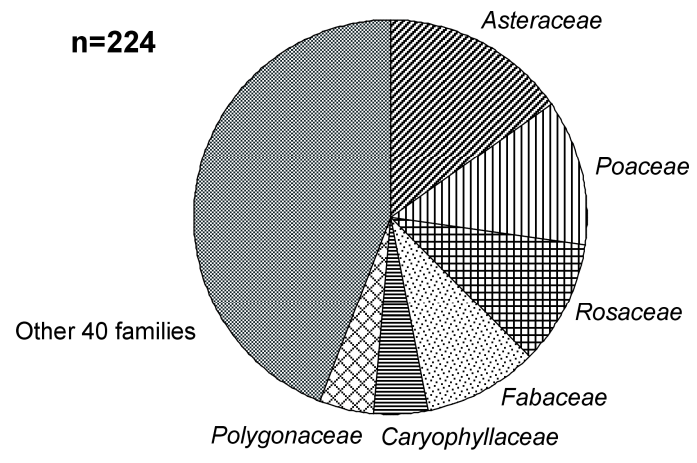

Fig. 1. Taxonomical spectrum of species found in the course of secondary succession.

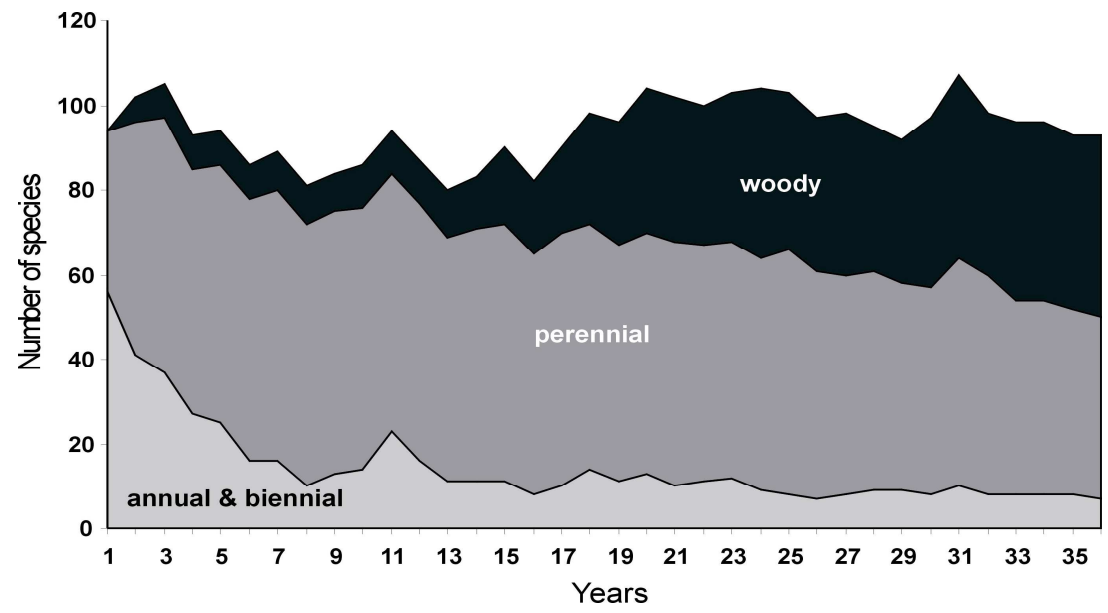

Fig. 2. Number of species observed in the course of secondary succession.

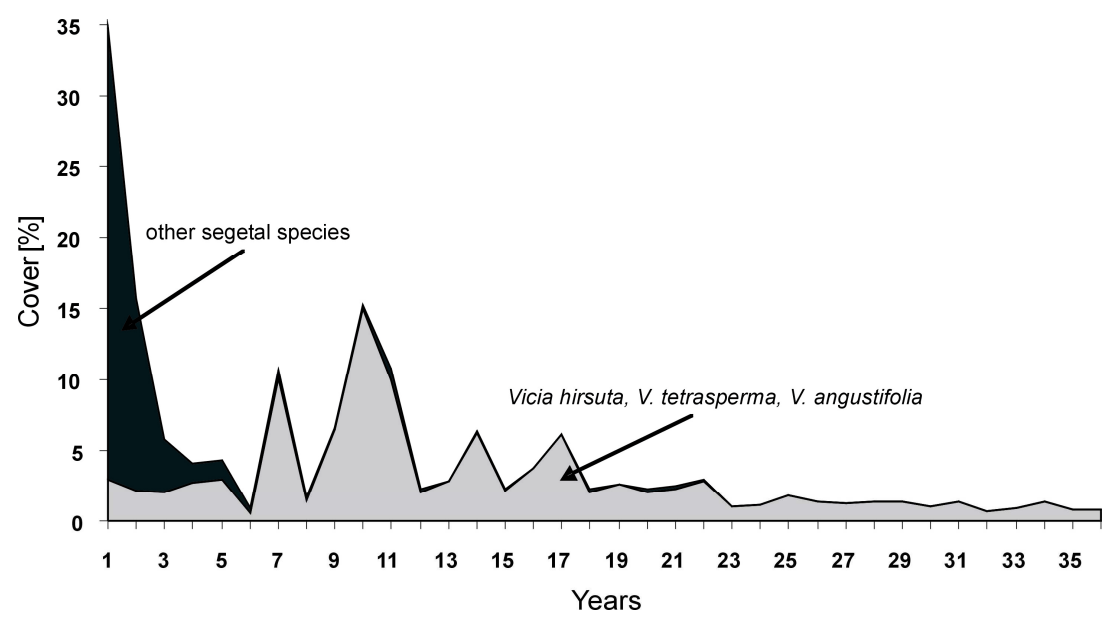

Fig. 3. Percentage cover of segetal species in the course of secondary succession. 


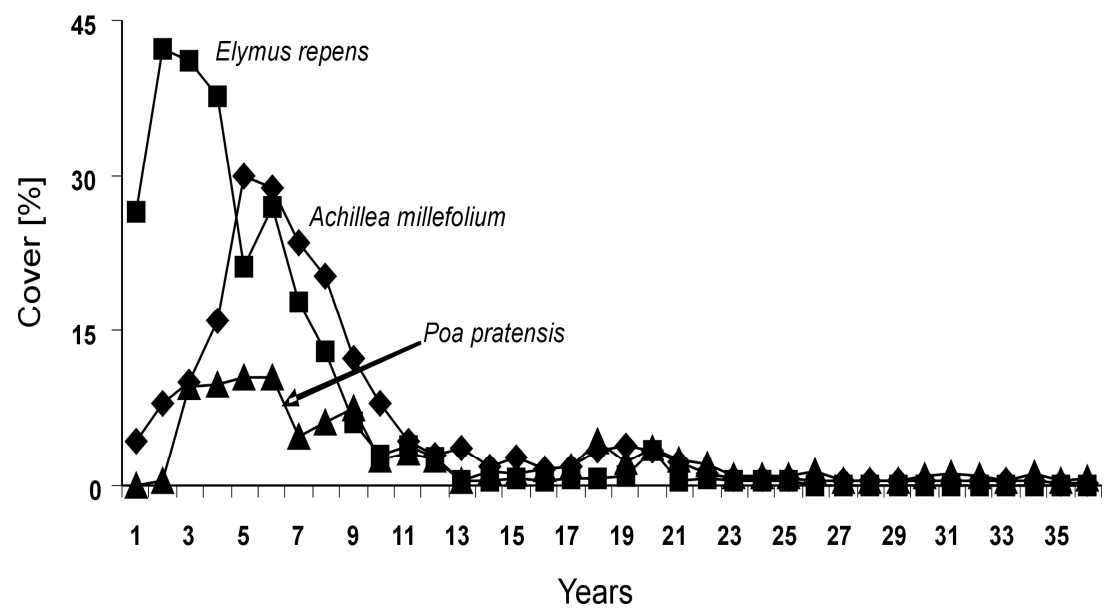

Fig. 4. Percentage cover of fallow species in the course of secondary succession.

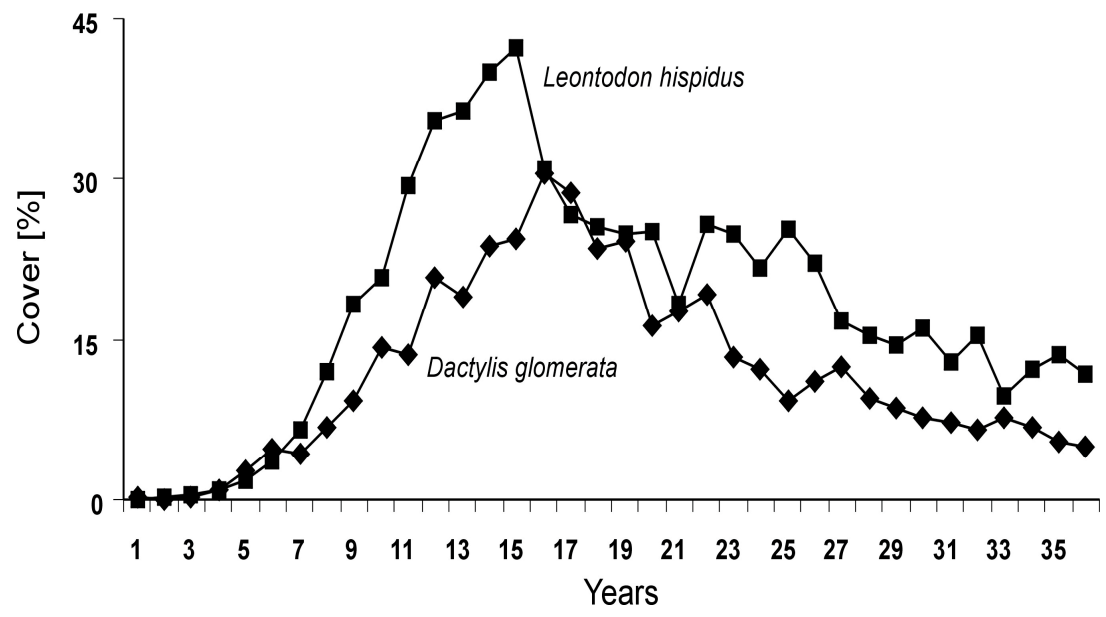

Fig. 5. Percentage cover of meadow species in the course of secondary succession.

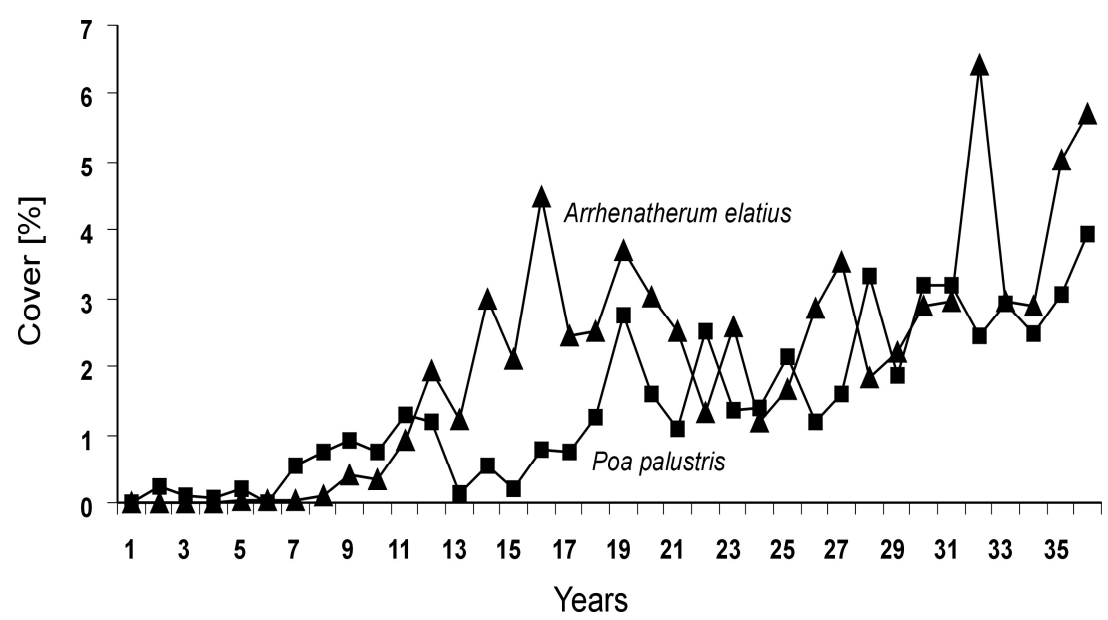

Fig. 6. Percentage cover of expansive grasses in the course of secondary succession. 
10. The first individuals of arborescent species outgrew herbaceous plants in year 11 of observation. In recent years the shrub layer reached an average of $20-25 \%$ cover (Fig. 7, 8). The shrub layer was mainly formed by trees, initially pioneer species (Salix caprea, Betula pendula), and currently, to a larger extent, by permanent forest components (Tilia cordata, Carpinus betulus; Fig. 8). So far, Salix aurita, has been the only shrub species with a high rate of cover in this layer.

11. The presence of a tree layer was first recorded in year 13 of observation. In year 21 it had a 50\% cover, and after year 23 the canopy cover stabilised at a level of 60-65\%. Initially, it was formed exclusively by pioneer species (Salix caprea, Betula pendula, Populus tremula), but currently also contains Acer platanoides and Tilia cordata (Fig. 9). Observations from recent years have demonstrated a gradual withdrawal of Salix caprea.

12. Between year 14 and 20 of observation the number of recorded tree species increased rapidly $(1987$ - 12, 1993 - 34). The majority of trees and shrubs observed for the first time during that period are species dispersed by birds (Fig. 10a), and Sorbus aucuparia was the first ornithochorous species, two seedlings of which emerged on experimental plots in year 14 of observation.

13. Melampyrum nemorosum, the most frequent pre-forest species, had the highest share in year 29 of observation (Fig. 11).

14. The share of juvenile specimens of tree species in the herb layer significantly increased after the formation of treestand, to reach $18.5 \%$ in year 36 of observation (Fig. 11).

15. In recent years the first forest herbaceous plants have occurred under the tree canopy (Convallaria majalis in year 26 of observation, Anemone nemorosa in year 29, Isopyrum thalictroides and Carex digitata in year 34); however, so far their role in the herb layer has been insignificant, due to their very low frequency and rate of cover. 


\section{DISCUSSION}

Forest return on abandoned fields has been described by many authors, and the obtained data demonstrates that the course of this process is diversified, and many secondary succession patterns developed based on empirical studies to a larger or smaller extent vary from succession theoretical model (OSBORNOVÁ et al. 1990; GLenN-Levin 1992; MCCOOK 1994; BARABASZ-Krasny 2002; FALIŃSKA 2003; BALCERKIEWICZ, PAWLAK 2006).

This results, among other things, from the fact that succession is a process strongly determined by starting conditions and surrounding vegetation (GLENNLEVIN 1992; MCCOOK 1994; FALIŃSKA 2003). The course of succession can also be modified by disturbances occurring during this long process, even if they are accidental or highly infrequent (TURNER et al. 1998; VON OHEIMB, BRUNET 2007). It has been demonstrated that the turnover of species and appearance of diverse floristic compositions in the long-term process of succession cannot always be predicted, even in the same object (OSBORNOVÁ et al. 1990; FALIŃSKA 2003, BLATT et al. 2005).

\subsection{Limitations}

In the Experimental Garden, the course of succession is influenced by factors which do not occur, or whose intensity is different, during a secondary succession which is undisturbed by man's influence. The most important of them are (ADAMOWSKI, KNOPIK 1996, supplemented):

1) an increased availability of ornithochorous species propagules, caused by the presence in the immediate vicinity of the plots of a considerable number of tree and shrub species producing fruits eaten by birds. This is one of the indirect causes of the ornithochore seedling "boom" observed in the plot (Fig. 10a). Data by PABJANEK (2003), also obtained from Białowieża Clearing as in our study, demonstrated how significant this increased availability of propagules is. In brushwood forests of several hundred to thousands of square meters in area, and distant from human dwellings, PABJANEK (2003) observed the occurrence of single ornithochorous 


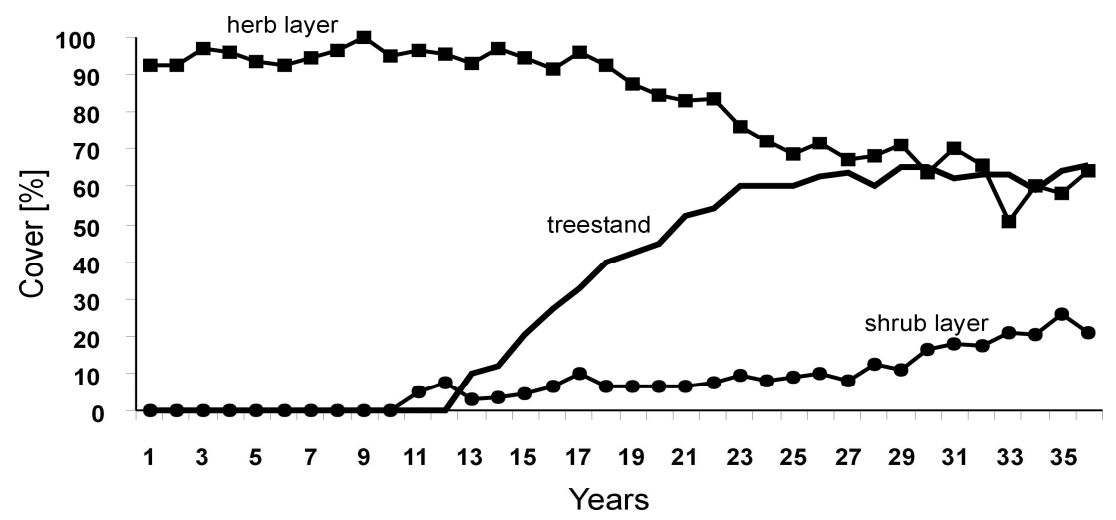

Fig. 7. Percentage cover of treestand, shrub layer and ground layer in the course of secondary succession (after BOMANOWSKA, ADAMOWSKI 2009, supplemented).

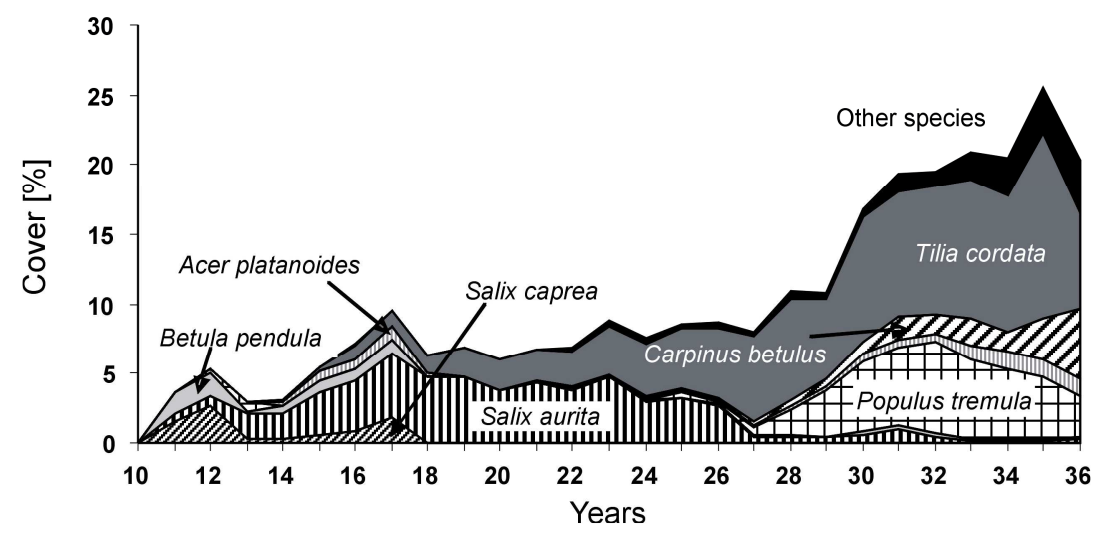

Fig. 8. Composition of the shrub layer in the course of secondary succession (after BOMANOWSKA, ADAMOWSKI 2009, supplemented).

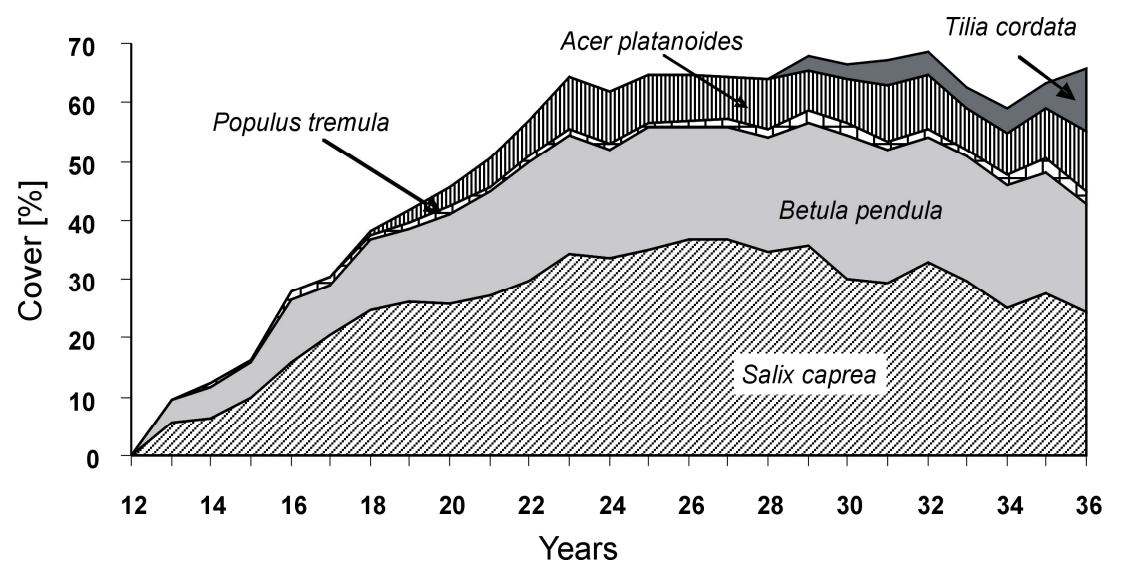

Fig. 9. Composition of the treestand in the course of secondary succession (after BOMANOWSKA, ADAMOWSKI 2009, supplemented). 

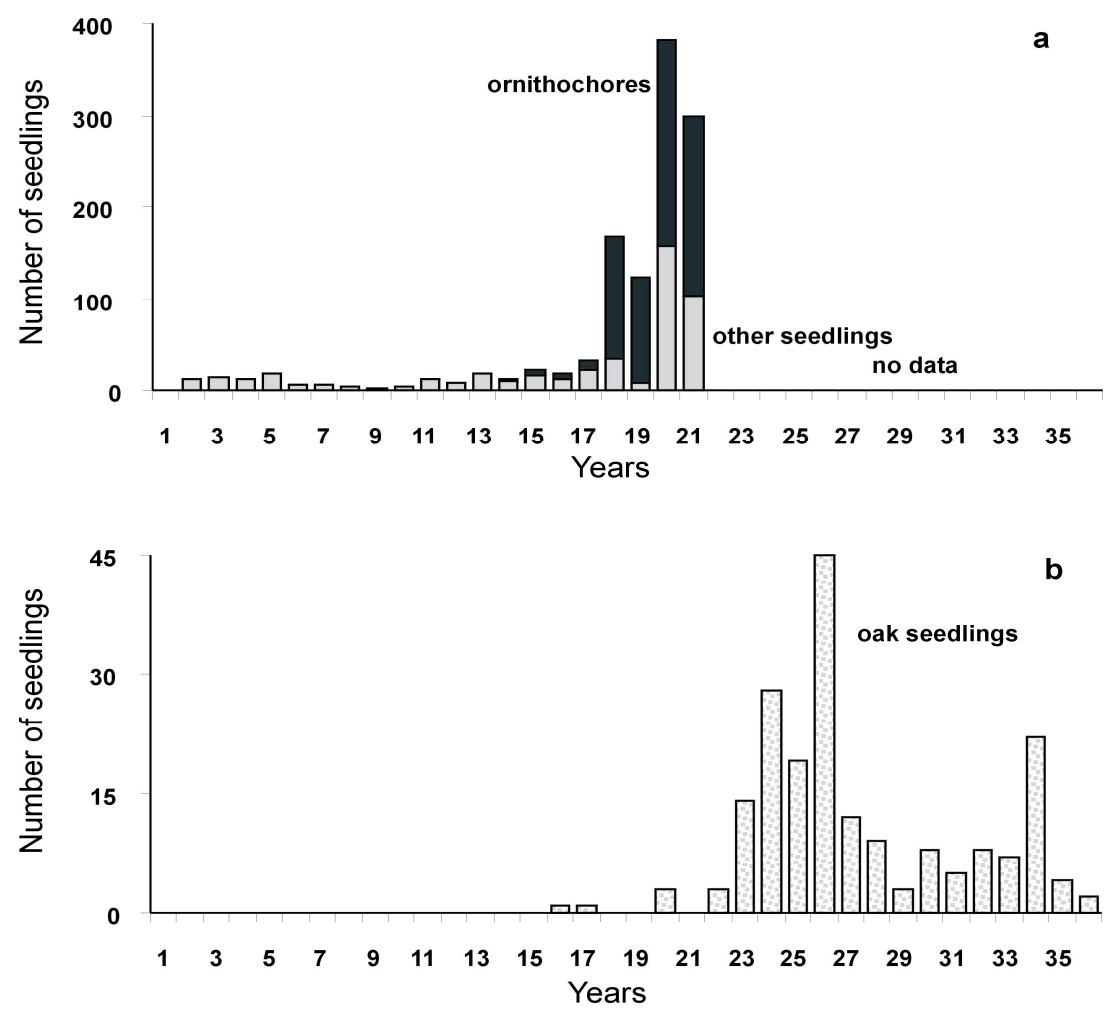

Fig. 10. Number of seedlings found in the course of secondary succession: (a) number of all seedlings and share of ornithochores; (b) number of oak seedlings (after BOMANOWSKA, ADAMOWSKI 2009, supplemented).

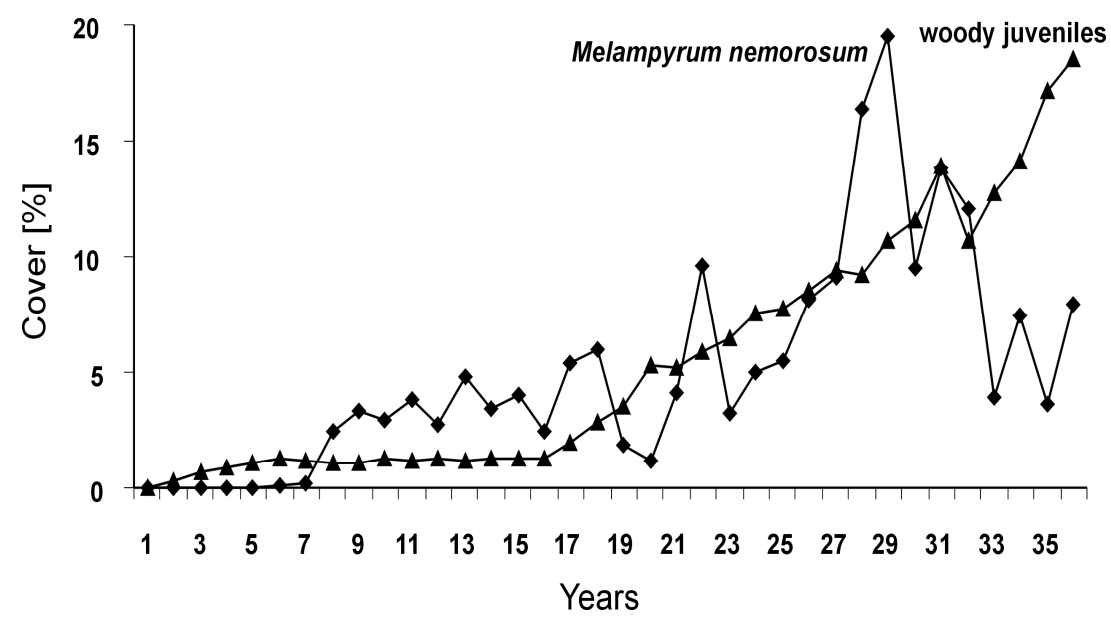

Fig. 11. Percentage cover of pre-forest species and woody juveniles in ground layer vegetation in the course of secondary succession. 
species, most frequently Frangula alnus and Sorbus aucuparia, while in our study over a dozen species per $170 \mathrm{~m}^{2}$ were found,

2) a very limited influence of herbivorous animals (European bison, red deer, wild boar, roe-deer, hare; only hares and the effects of their activity were already seen), caused by fencing in and the proximity of human dwellings; these animals can naturally significantly affect the succession process, eating part of the biomass produced, mechanically destroying, browsing and debarking young trees, displacing and treading seeds into the soil, manuring the soil with faeces, creating favourable conditions for germination (by damaging the vegetation and uncovering the inorganic soil horizons), limiting the competitive influence of grassy vegetation and so forth. The limited influence of large herbivores seems to be a serious shortcoming in our study, particularly in view of recent research on the role of these animals in seed dispersal (COUVREuR et al. 2005; WILLIAMS et al. 2007; JAROSZEWICZ et al. 2009),

3) yearly, and concentrated within the short observation period, damaging of plants (treading paths, combing the ground-cover vegetation for seedlings, unwittingly breaking branches), which may significantly affect the emergence and survival rate of the seedlings (seedlings developed in heavily shaded places often fail to survive if uncovered suddenly, especially when the weather is hot and dry),

4) inclusion in the succession process of trees and shrubs that are not native to the the Białowieża Forest (Acer pseudoplatanus, Tilia platyphyllos, Pinus strobus, Cotoneaster sp., and suchlike; ADAMOWSKI, BOMANOWSKA 2007b, 2008) and whose role in the community that is forming is for the time being difficult to predict.

In addition, the succession process is largely affected by factors resulting from the small size of the research site, for example strong sideways light penetration, litter drifting, decreased air humidity in comparison to the interior of the forest community, etc. BARKMAN (1989) in his analysis of mixed forest in Northern America, evaluated the area of phytocoenosis required for its typical formation per 3 ha. Transitional zones may be 10-15, and even $30 \mathrm{~m}$ wide. For comparison, the surface of all of section $\mathrm{C}$ is as low as $400 \mathrm{~m}^{2}$, while its breadth is $15 \mathrm{~m}$. Study plots in our series are rather small but this is a compromise between requirements and capabilities developed during project design. Each year observations in sector $\mathrm{C}$ alone require 
approximately 20 hours, and the labour intensity increases with the development of the vertical community structure and the occurrence of first spring geophytes.

The fragment of the succession process analysed so far is only $1 / 10$ of its predicted duration. Assuming that a researcher is able to actively participate in observations for 25-30 years, there will be at least another 10 generations of researchers required to complete these observations, and to fully analyse and publish the results.

Owing to the fact that the course of succession is influenced by accidental factors, such as extreme weather conditions, mass occurrence of insects and other animals, and natural disasters (TURNER et al. 1998; VON OHEIMB, BRUNET 2007), making projections far into the future is very difficult. Small size study plots, where one tree falling can significantly influence results, are particularly prone to such effects. Therefore, our predictions, especially concerning the terminal succession stage (Fig. 12), are highly hypothetical.

\section{2. Patterns}

In view of the past observations conducted on experimental plots in the Białowieża Clearing, forest return to the abandoned field is a process similar to that predicted by the theoretical succession model (Fig. 2, 7, 12). Short-lived plants were eliminated by perennials associated with grass communities, which were later replaced by tree species. Despite the fact that only $1 / 10$ of the time required for the restoration of mature oak-hornbeam forest elapsed (360 years; FALIŃSKI 2001), the first forest plants already occurred. In a considerably shorter time (in year 6 of observation), plants from this group were observed in the Wielkopolski National Park, but the study site there is directly surrounded by patches of oak-hornbeam forest communities (BALCERKIEWICZ, PAWLAK 2006), while sector C is located 115$140 \mathrm{~m}$ from the Palace Park border, the most significant source of seed fall (see ADAMOWSKI, KNOPIK 1996). 


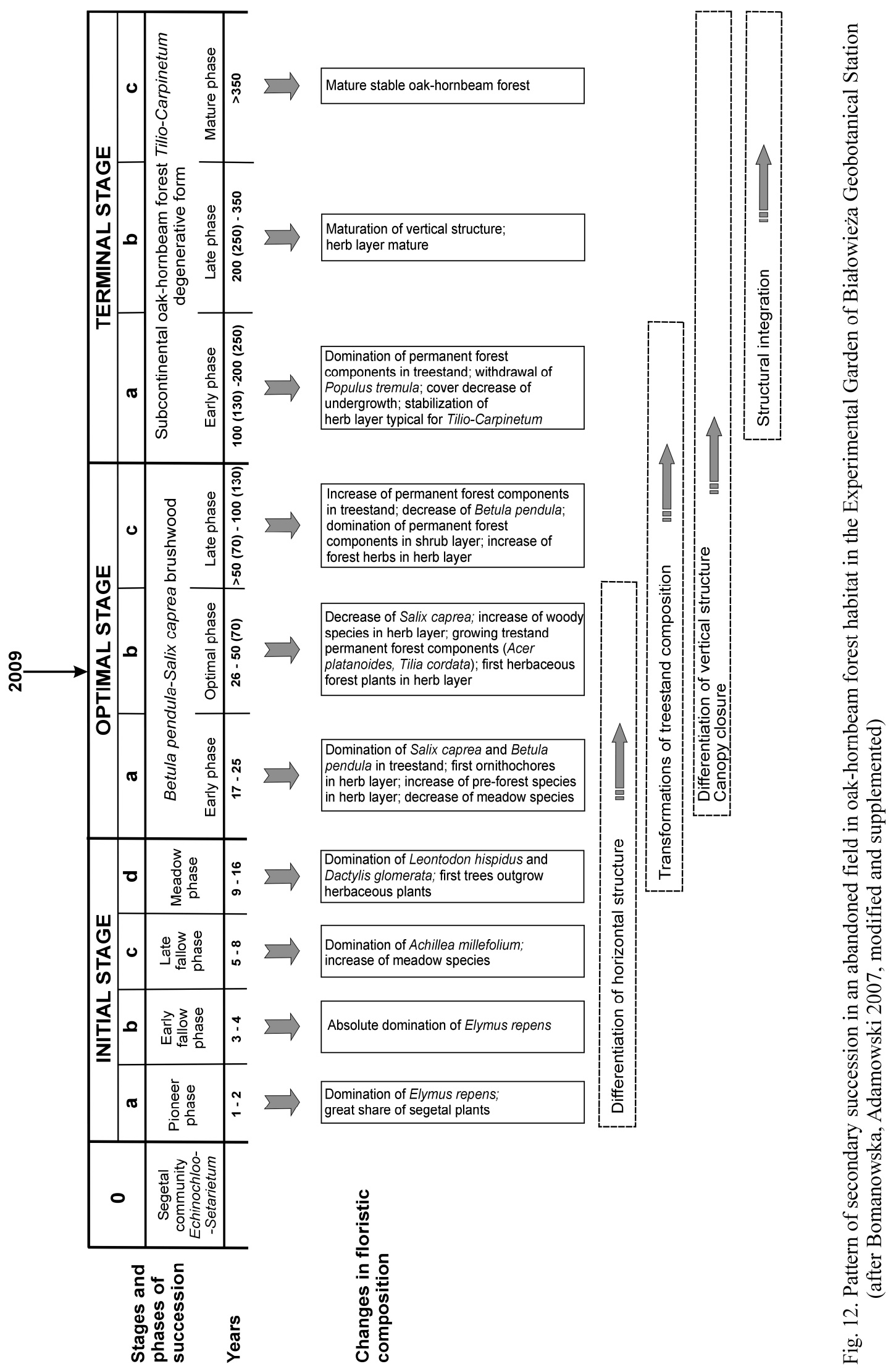


As in many other succession series, fast withdrawal of short-lived species has also been observed on the studied plots (OSBORNOVÁ et al. 1990; FALIŃSKI 1986; DeBUSSCHE et al. 1991; DöLLE et al. 2008), except for three Vicia species, i.e. Vicia angustifolia, $V$. tetrasperma and $V$. hirsuta, which had their maximum cover rate when other terophytes almost completely withdrew (ADAMOWSKI, BOMANOWSKA 2007c; Fig. 3). The survival of Vicia spp. is possibly associated with the formation of a persistent seed bank by them and strong sideways light penetration of the study plot. The presence of such early-succession species, albeit most often in a sterile form, has also been observed at considerably advanced succession stages in other study series (DöLLE et al. 2008).

Up to the present time, in the course of the experiment covering approximately $1 / 10$ of the duration of the entire oak-hornbeam succession series, 224 species are involved, which is $70 \%$ of the species pool predicted by FALIŃSKI (2001). It cannot be excluded that their number will exceed 320, owing to the close proximity of study plots to the Palace Park and private gardens with numerous alien tree species. A similar number of species was observed in a corresponding study series (BALCERKIEWICZ, PAWLAK 2006; DöLlE et al. 2008). However, this similarity largely results from the comparable diversity of local floras and the size of study plots.

Carried out observations (Fig. 2) do not confirm the directional changes in species diversity in the course of succession observed by some authors (DEBUSSCHE et al. 1991; BLATT et al. 2005). Moreover, it will be difficult to find them in the future if predictions by FALIŃSKI (2001) on the number of species involved in the formation of the final forest community (90 species) are confirmed. Similar patterns of fluctuating species diversity as observed were found in successional studies conducted in Germany (DöLLE et al. 2008).

Strictly separated successional stages are difficult to distinguish in our series of observations. Neither the relay of species theory, nor the initial species composition theory have any practical confirmation here. Therefore, we can assume, following FALIŃSKA (2003), that in our case succession results more from various species replacement mechanisms than from being the consequence of predictable 
species compositions. Otherwise, it would be difficult to explain the abovedescribed behaviour of Vicia spp. or the surprising phenomenon of the constant increase in coverage for typical grassland species, i.e. Arrhenatherum elatius and Poa palustris after the terrain was already occupied by trees (Fig 6; BOMANOWSKA, ADAMOWSKI 2007a).

Interestingly, invasive herbaceous species were almost entirely absent in our series of observations. Results of previous studies conducted by the authors on the same physiographical area (the Białowieża Clearing) demonstrated that many geographically alien plants, including herbaceous plants (Solidago gigantea, Erigeron annuиs, E. ramosus) are involved in spontaneous secondary succession on abandoned farming land (ADAMOWSKI, BOMANOWSKA 2008), while a high number of non-native tree species were found in the described series. However, so far it is difficult to establish which species will permanently form the restoring forest community. The presence of invasive species, such as Solidago gigantea, sometimes demonstrating a high cover rate, has also been observed in other succession series (DöLLE et al. 2008).

The crucial role in the course of the analysed succession is played by two species groups which, according to FALIŃSKA (1989) were defined as succession promoters and inhibitors. Succession promoters are pioneer tree species: Salix caprea, Betula pendula, Populus tremula, whose shading of the soil and production of litter contributed to the withdrawal of meadow species (Fig. 7, 9, 12), and also provided rest sites for birds dispersing numerous tree and shrub seeds (Fig. 10a; BOMANOWSKA, ADAMOWSKI 2007b). The first seedlings of ornithochores occurred on experimental plots when the tree layer cover reached approximately 30\%, and their number rapidly increased during the subsequent years (Fig. 10a; ADAMOWSKI, KNOPIK 1996). Numerous Quercus robur seedlings occurred even later (Fig. 10b). The succession also seems to be promoted by Melampyrum nemorosum (Fig. 11), which dies back quite early in the summer, forming in consequence gaps for the germination of forest species. The role of persistent forest components (Acer platanoides, Carpinus betulus, Tilia cordata) accelerating succession has been pronounced in recent years. A similar role of succession promoters in the region of 
the Białowieża Primeval Forest is played by woody species (Juniperus communis, Populus tremula) in the secondary succession of the coniferous forest series (FALIŃSKI 1986, 1998), as well as Alnus glutinosa and Salix cinerea in the riparian forest series (FALIŃSKA 1989, 2003).

Elymus repens, a clonal species, and Leontodon hispidus, inhibiting the emergence of tree seedlings owing to its rosette structure, can be considered succession inhibitors (BOMANOWSKA, ADAMOWSKI 2007b). Both species reached very high cover rates in different phases of the initial stage of the secondary succession (Fig. 4, 5): 70\% for Elymus repens, and 80\% for Leontodon hispidus on single plots. The inhibiting effect of these species on the germination of tree seeds is confirmed by the very low number ( 23 specimens) of pioneer tree species in the first years of observation, as well as the increase in the number of tree and shrub seedlings after the formation of a tree stand and the withdrawal of inhibitors (BOMANOWSKA, ADAMOWSKI 2007b). Elymus repens also occurred as a dominant in other succession series (OSBORNOvÁ et al. 1990; BLATT et al. 2005), although not always during a similar period.

\subsection{Prognosis}

In forthcoming years we expect an increase in shrub layer cover associated with the growth of numerous lime, hornbeam and oak individuals, as well as vegetative colonisation of aspen. Increasing shading and deposition of litter demonstrating more forest features should accelerate the withdrawal of the remaining meadow plants, as well as Melampyrum nemorosum, and form a gap to be colonized by forest species. We expect the occurrence of other forest species in the herb layer and the increase of those already present (see Results).

During the coming decades the treestand cover will probably increase, as other lime specimens grow higher and hornbeams reach this layer. The features of the litter will then be changed (compare FALIŃSKI et al. 1988) from that composed mainly by the leaves of Betula pendula, Salix caprea and Populus tremula, promoting meso-xerophilous species, into more easily-degradable litter containing 
more Tilia cordata and Carpinus betulus leaves, promoting meso-hygrophilous species.

Salix caprea should be the first pioneer tree species to withdraw. This tree rarely exceeds ages of 50-60 years (FALIŃSKI 1997), and already, in year 36 of observation, it is demonstrating reduced growth speed and vitality (Fig. 9). Betula pendula and Populus tremula in forest communities reach ages of 80-100 years (ZARZYCKI 1979; FALIŃSKI 1998). Mature individuals of these species have not demonstrated reduced vitality on the study plot so far, although they have started losing lower branches, and their canopies grow outwards from the plot. Inhibited recruitment of Betula pendula has already been observed. Populus tremula 'crowds in' vegetatively in small-size gaps between the canopies of other trees. Therefore, we assume that this species will be the last pioneer tree to withdraw, or it may even survive as a component of the final treestand. A similar sequence of self-thinning of pioneer tree species was observed by FALIŃSKI et al. (1988) in the restoration of oak-hornbeam forest on strip clearcuts in the Białowieża National Park.

The role of oak, insignificant so far, in the shrub layer and its absence in the treestand (Fig. 8, 9) results from the dispersal strategy of this tree and the slow growth in the juvenile period (DANIELEWICZ, PAWLACZYK 2006). This species is characterised by a relatively high survival rate of juvenile specimens under experimental conditions. However, the potential incorporation of Quercus robur to the treestand will probably be observed later, by future generations of researchers. This incorporation may be inhibited by more shade-tolerant species like hornbeam (FALIŃSKI, PAWLACZYK 1993) and lime (FALIŃSKI, PAWLACZYK 1991).

We expect that the longest time will be required for the restoration of the mature vertical community structure. The tallest birch specimens already exceed 20 $\mathrm{m}$, which is nearly a half of the height attained by the tallest oaks, limes and maples in Białowieża Primeval Forest (FALIŃSKI 1986). The trees that will form the future treestand are considerably smaller: maples grow 10-12 m high, and limes to 8-9 m.

The achievement of species combination typical for a mature oak-hornbeam forest is rather improbable in these experimental conditions because of the small size of the study plot (see "Limitations"). The expected result is rather the development 
of degenerative forms of oak-hornbeam forest similar to the one described by BALCERKIEWICZ and co-workers (BALCERKIEWICZ et al. 1992) - a facies with Poa nemoralis, connected with forest edges. The presence of more light-demanding nonforest species under these conditions is not excluded, especially on the edge of the plot.

Results presented in our paper add to the intense debate on the ideal succession model. Even if we assume that the process we describe has a local nature, it may still contribute to the explanation of succession causes and mechanisms. Individual studies conducted in different geographical regions and habitat conditions can establish a useful theoretical background for the design of a new model, and even, considering the variety of succession pathways in one area, of several succession models.

\section{CONCLUSIONS}

- Our study supports the view that succession is a process which is largely dependent on the initial conditions and surrounding vegetation.

- Result obtained up to this moment confirm that undisturbed secondary succession on an abandoned field leads from a typical segetal community to the formation of a juvenile treestand and allows for the assumption that the forest will return to the abandoned field.

- Forest return to the abandoned field is a process similar to that predicted by the theoretical succession model: short-lived plants were eliminated by perennials associated with grass communities, which were later replaced by woody species.

- However, our observations do not confirm the directional changes in species diversity in the course of succession. Neither the relay of species theory, nor the initial species composition theory have any practical confirmation here.

- Pioneer tree species are succession promoters by shading of the soil and production of litter which contributed to the withdrawal of meadow species, and also by providing rest sites for birds dispersing numerous tree and shrub seeds. 
Role of pre-forest Melampyrum nemorosum and persistent forest components accelerating succession has been pronounced in recent years.

- Clonal grass Elymus repens and rosette-forming Leontodon hispidus can be considered succession inhibitors.

- Role of non-native species, especially trees and shrubs, in the community that is forming is for the time being difficult to predict.

\section{Acknowledgements}

We wish to cordially thank Prof. A. U. Warcholińska for many years of common observations in the Experimental Garden of the Białowieża Geobotanical Station and Mr. Peter Foulds for linguistic corrections.

\section{REFERENCES}

ADAMOWSKI, W., KNOPIK, A. 1996. Ornithochorous species penetration onto abandoned farmland during secondary succession. Phytocoenosis 8 (N.S.) Sem. Geobot. 4: 97-110.

ADAmowski, W., BomanowsKA, A. 2007a. Ekspansja Trisetum flavescens (Poaceae) na Polanie Białowieskiej. Fragm. Flor. Geobot. Polonica Suppl. 9: 97105.

ADAMOWSKI, W., BomanowsKa, A. 2007b. Udział drzew i krzewów obcego pochodzenia $\mathrm{w}$ procesie zasiedlania gruntów porolnych $\mathrm{w}$ rejonie Puszczy Białowieskiej. Acta Botanica Warmiae et Mazuriae 4: 309-320.

ADAMOWsKI, W., BomanowsKA, A. 2007c. Utrzymywanie się chwastów segetalnych w toku sukcesji wtórnej na porzuconym polu. In: Botanika w Polsce - sukcesy, problemy, perspektywy. Streszczenia referatów i plakatów. 54. Zjazd Polskiego Towarzystwa Botanicznego. Szczecin, 3-8 września 2007, p. 75.

ADAMOWsKI, W., BomAnowsKA, A. 2008. Zmiany użytkowania gruntów na obrzeżach cennych obiektów przyrodniczych a wkraczanie nierodzimych gatunków roślin. Przegl. Przyr. 19(3-4): 3-17. 
ADAmowsKi, W., BomanowsKa, A. 2009. Zmiany udziału traw na nienawożonej łące kośnej w Puszczy Białowieskiej w ciągu 24 lat. Fragm. Flor. Geobot. Polonica 16(2): 377-386.

Balcerkiewicz, S., Kasprowicz, M., PIETRZaK, M. 1992. Landscape-geobotanical basis for a typology of the man-made forest boundary. Ekológia (CSFR) 11(1): $29-47$.

Balcerkiewicz, S., PAwlak, G. 2006. Dynamics of small clearing flora in the biodiversity context. Biodiv. Res. Conserv. 1-2: 114-122.

BARABASZ-KRASNY, B. 2002. Sukcesja roślinności na łąkach, pastwiskach i nieużytkach porolnych Pogórza Przemyskiego. Fragm Flor. Geobot. Polonica Suppl. 4: 3-81.

BARKMANN, J.J. 1989. A critical evaluation of minimum area concepts. Vegetatio 85(1-2): 89-104.

Blatt, S.E., Crowder, A., Harmsen, R. 2005. Secondary succession in two southeastern Ontario old-fields. Plant Ecology 177: 25-41.

Bomanowska, A., Adamowski, W. 2007a. Grasses (Poaceae) in secondary succession of oak-hornbeam series in Białowieża Forest. In: L. FrEY (ed.), Biological issues in grasses. W. Szafer Institute of Botany, pp. 131-143.

Bomanowska, A., Adamowski, W. 2007b. Promotorzy i inhibitorzy w sukcesji serii grądowej na Polanie Białowieskiej. In: Botanika w Polsce - sukcesy, problemy, perspektywy. Streszczenia referatów i plakatów. 54. Zjazd Polskiego Towarzystwa Botanicznego. Szczecin, 3-8 września 2007, pp. 78-79.

Bomanowska, A., Adamowski, W. 2009. The role of woody species in the secondary succession under monitored conditions (Bialowieza Forest, NE Poland). In: D. Ivanova (ed.), Plant, fungal and habitat diversity investigation and conservation. Proceedings of IV Balkan Botanical Congress, Sofia, 20-26 June 2006. Institute of Botany, Bulgarian Academy of Sciences, Sofia, pp. 291295.

BORNKAMM, R. 2007. Fifty years vegetation development of a xerothermic calcareous grassland in Central Europe after heavy disturbance. Flora 201: 249267. 
BRADY, C.J., Noske, R.A. 2010. Succession in bird and plant communities over a 24-year chronosequence of mine rehabilitation in the Australian monsoon tropics. Restoration Ecology 18: 855-864.

Couvreur, M., Cosyns, E., Hermy, M., Hoffmann, M. 2005. Complementarity of epi- and endozoochory of plant seeds by free ranging donkeys. Ecography 28: $37-48$.

DANielewicz, W., PAWlaczyK, P. 2006. Rola dębów w strukturze i funkcjonowaniu fitocenoz. In: W. BugAŁA (ed.), Dęby. Nasze Drzewa Leśne 11. Instytut Dendrologii PAN, Poznań - Kórnik, pp. 474-564.

Debussche, M., Escarré, J., Lepart, J., Houssard, C., Lavorel, S. 1996. Changes in mediterranean plant succession: old-fields revisited. J. Veg. Sci. 7: $519-526$.

Dölle, M., Bernhardt-Römermann, M., PArth, A., Schmidt, W. 2008. ㅁhangngess. in life history trait composition during undisturbbed old-field suc- successsion. Flora 203: 508-522.

DZWONKO, Z. 2007. Przewodnik do badań fitosocjologicznych. Instytut Botaniki Uniwersytetu Jagiellońskiego. Wydawnictwo Sorus. Poznań - Kraków.

FALIŃSKA, K. 1989. Plant population process in the course of forest succession in abandoned meadows. I. Variability and diversity of floristic compositions, and biological mechanisms of species turnover. Acta Soc. Bot. Pol. 58: 439-465.

FALIŃSKA, K. 2003. Alternative pathways of succession: species turnover patterns in meadows abandoned for 30 years. Phytocoenosis 15 (N.S.) Archiv. Geobot. 10: $1-104$.

FALIŃSKI, J.B. 1977. Research on vegetation and plant population dynamics conducted by Białowieża Geobotanical Station of the Warsaw University in the Białowieża Primeval Forest and in the environ (1952-1977). Phytocoenosis 6(1/2): 1-148.

FALIŃSKI, J.B. (ed.) 1978. Vegetation dynamics. Proceedings of the Third Symposium of the Working Group on Succession Research on Permanent Plots, held at the Białowieża Geobotanical Station, Warsaw University, Białowieża, August 30 September 2, 1977. Phytocoenosis 7( 1/2/3/4): 1-384. 
FALIŃSKI, J.B. 1986. Vegetation dynamics in temperate lowland primeval forests. Ecological studies in Białowieża Forest. Geobotany 8. Dr W. Junk Publishers, Dordrecht/Boston/Lancaster, pp. 1-537.

FALIŃSKI, J.B. 1997. Declines in populations of Salix caprea L. during forest regeneration after strong herbivore pressure. Acta Soc. Bot. Pol. 66.1: 87-109.

FALIŃSKI, J.B. 1998. Dioecious woody pioneer species (Juniperus communis, Populus tremula, Salix sp. div.) in the secondary succession and regeneration. Phytocoenosis 10 (N.S.) Suppl. Cartogr. Geobot. 8: 1-156.

FALIŃSKI, J.B. 2001. Przewodnik do długoterminowych badań ekologicznych. Wydawnictwo Naukowe PWN, Warszawa.

FALIŃSKI, J.B. 2002. Białowieża Geobotanical Station. Long-term studies. Data basis on the vegetation and environment (1952-2002). Phytocoenosis 14 (N.S.) Suppl. Bibl. Geobot. 14: 1-200.

FALIŃSKI, J.B. 2003. Long-term studies on vegetation dynamics: some notes on concepts, fundamentals and conditions. Community Ecology 4(1): 107-113.

FALIŃSKI, J.B., CANUllo, R., BIAŁY, K. 1988. Changes in herb layer, litter fall and soil properties under primary and secondary tree stands in a deciduous forest ecosystem. Phytocoenosis 1 (N.S.) 1-49.

FALIŃSKI, J.B., PAWLACZYK, P. 1991. Zarys ekologii. In: S. BıAŁOBOK (ed.), Lipy Tilia cordata Mill., T. platyphyllos Scop. Nasze Drzewa Leśne 15. Agencja Arkadia, Poznań, pp. 145-236.

FAliŃsKi, J.B., PAWlaczyK, P. 1993. Zarys ekologii. In: W. BugaŁa (ed.), Grab zwyczajny Carpinus betulus L. Nasze Drzewa Leśne 9. SORUS, Poznań - Kórnik, pp. 157-263.

FAliński, J.B., Warcholińska, A.U., AdAmowski, W., Bomanowska, A. 2004. Sukcesja wtórna na porzuconych polach w świetle średnioterminowych badań na stałych powierzchniach. In: Sukcesja wtórna roślinności na gruntach porolnych. XXVIII Krajowa Konferencja Naukowa z cyklu „Rejonizacja chwastów segetalnych w Polsce". Olsztyn, 8-10 lipca 2004, p. 1.

Foster, B.L., Tilman, D. 2000. Dynamic and static views of succession: Testing the descriptive power of the chronosequence approach. Plant Ecology 146: 1-10. 
Glenn-Lewin, D.C., Peet, R.K., Veblen, T.T. (eds) 1992. Plant succession. Theory and prediction. Chapman \& Hall, London - Glasgow - New York Tokyo - Melbourne - Madras.

Jaroszewicz, B., PirożNiKow, E., SAGEHorn, R. 2009. Endozoochory by European bison (Bison bonasus) in Białowieża Primeval Forest across a management gradient. For. Ecol. Manage. 258: 11-17.

JOHNSON, E.A., MYIANISHI, K. 2008. Testing the assumptions of chronosequences in succession. Ecol. Lett. 11: 419-431.

MCCoOK, L.J. 1994. Understanding ecological community succession: casual models and theories, a review. Vegetatio 110: 115-147.

Mirek, Z., PięKoŚ-Mirkowa, H., Zając, A., ZająC, M. 2002. Flowering plants and pteridophytes of Poland - a checklist. In: Z. MIREK (eds), Biodiversity of Poland 1. W. Szafer Insitute of Botany, Polish Academy of Sciences, Kraków.

MYsteR, R.W., MALAHY, M.P. 2008. Testing the assumptions of chronosequences in succession. Can. J. For. Res. 38: 3133-3138.

Osbornová, J., KovÁrovÁ, M., LePŠ, J., PrACH, K. 1990. Succession in abandoned fields. Studies in Central Bohemia, Czechoslovakia. Kluwer Academic Publishers, Dordrecht.

PABJANEK, P. 2003. Kształtowanie się zapustów leśnych w warunkach puszczańskiej polany osadniczej. Praca doktorska, Uniwersytet Warszawski, Warszawa - Białowieża.

PICKETT, S.T.A. 1982. Population patterns through twenty years of oldfield succession. Vegetatio 49: 5-59.

SCHMIDT, W. 2006. Biodiversity and plant productivity in a grassland succession: effects of nutrient levels and disturbance regimes. Pol. Bot. Stud. 22: 437-448.

Turner, M.G., BAKer, W.L., Peterson, C.J., Peet, R.K. 1998. Factors influencing succession: lessons from large, infrequent natural disturbances. Ecosystems 1: $511-523$.

VANKAT, J.L., SNYDER, G.W. 1991. Floristic of a chronosequence corresponding to old field-deciduous forest succession in Southwestern Ohio. I. Undisturbed vegetation. Bull. Torr. Bot. Club 118: 365-376. 
VON OHEIMB, G., BRUNET, J. 2007. Dalby Söderskog revisited: long-term vegetation changes in a south Swedish deciduous forest. Acta Oecol. 31: 229-242.

WiLliams, S.C., WARD, J.S., RAMAKRISHNAN, U. 2008. Endozoochory by whitetailed deer (Odocoileus virginianus) across a suburban/woodland interface. For. Ecol. Manage. 255: 940-947.

ZARZYCKI, K. 1979. Zarys ekologii. In: S. BiAŁoboK (ed.), Brzozy Betula L. Nasze Drzewa Leśne 7. PWN, Warszawa - Poznań, pp. 265-291. 